The

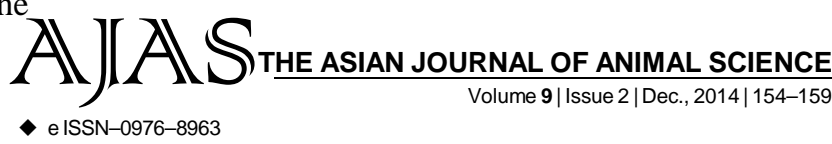

DOI : 10.15740/HAS/TAJAS/9.2/154-159

Visit us | www.researchjournal.co.in

RESEARCH ARTICLE........

\title{
Development of molecular tools to differentiate and detect adulteration of common meat species
} \author{
MAYURA R. PATIL, ANILKUMAR S. BANNALIKAR, SWATI R. GUNJAL AND PREETI H. ADMANE .
}

Author for Corresponding -

MAYURA R. PATIL

Department of Animal

Biotechnology, Bombay

Veterinary College, MUMBAI (M.S.)

INDIA

Email: dr.mayurapatil@gmail.com

See end of the article for

Coopted authors'

\begin{abstract}
Meat is one of the major sources of proteins for the human beings. Adulteration of good quality meat with poor is one of the widespread problems of the meat industry. The PCR based methods developed in the recent times are suggested to facilitate precise and quick detection of meat animal species overcoming the disadvantages of conventional methods. The present investigation was undertaken with a view to evaluate the efficacy of PCR-RFLP analysis of mt 12S rRNA gene in identification of major meat animal species viz., cattle, buffalo, sheep and goat. Amplification of $456 \mathrm{bp}$ of mt. 12S rRNA gene by PCR from meat samples of all the species followed by restriction digestion of the PCR products with $A l u \mathrm{I}, H h a \mathrm{I}, B s p \mathrm{TI}$ and $A p o \mathrm{I}$ in separate reactions. Characteristic RFLP patterns were generated specific for each species that allowed their accurate identification. The method was also evaluated for its efficacy in identification of species from adulterated meat samples. Buffalo meat: sheep meat (mutton) and buffalo meat: goat meat (chevon) samples were mixed in different proportions (viz., 50:50, 60:40, 70:30, 80:20, 90:10 and 95:05) in a manner similar to that of unadulterated samples. Among the adulterated meat samples, accurate identification of both the species was possible in combinations: 50:50, 60:40, 70:30 and 80:20 consistently in 15 experiments. The results of present study indicated that the PCR-RFLP analysis of $\mathrm{mt} 12 \mathrm{~s}$ rRNA gene could be potentially useful tool for detection of meat animal species.
\end{abstract}

KEY WORDS...... Meat species, Adulteration, mt 12S rRNA gene, PCR-RFLP, Restriction enzyme

HOW TO CITE THIS ARTICLE - Patil, Mayura R., Bannalikar, Anilkumar S., Gunjal, Swati R. and Admane, Preeti H. (2014). Development of molecular tools to differentiate and detect adulteration of common meat species. Asian J. Animal Sci., 9(2) : 154-159.

ARTICLE CHRONICLE - Received : 26.07.2014; Revised : 03.11.2014; Accepted : 18.11.2014 